\title{
PENGEMBANGAN BAHAN AJAR ENGLISH FOR SPECIFIC PURPOSE BERBASIS TIK
}

\author{
Muhammad Yaumi \\ Fakultas Tarbiyah dan Keguruan UIN Alauddin Makassar \\ Kampus II: Jalan Sultan Alauddin Nomor 36 Samata-Gowa \\ Email: muhammadyaumi@yahoo.com
}

\begin{abstract}
Abstrak:
Penelitian ini tentang pengembangan bahan ajar Bahasa Inggris untuk Tujuan Khusus berbasis teknologi komunikasi dan informasi. Tujuan penelitian ini adalah untuk mengetahui jenis bahan ajar bahasa Inggris yang digunakan dalam pembelajaran, mengembangkan bahan ajar ESP yang mengintegrasikan TIK, dan mengkaji efektivitas pelaksanaan pembelajaran dengan menggunakan bahan ajar ESP berbasis TIK yang dikembangkan. Jenis penelitian ini adalah penelitian dan pengembangan. Teknik pengumpulan data yang digunakan dalam penelitian ini adalah observasi wawancara, dokumen, portofolio, dan tes. Teknik analisis data menggunakan mixed method. Hasil penelitian menunjukkan bahwa Bahan ajar bahasa Inggris untuk tujuan khusus yang digunakan di UIN Alauddin masih tradisional karena lebih fokus menggunakan buku teks, papan tulis, dan interaksi tatap muka. Pembelajaran bahasa Inggris untuk tujuan khusus dengan menggunakan TIK telah dikembangkan secara sistematis dan direvisi berdasarkan rekomendasi. Penggunaan ICT dalam pembelajaran bahasa Inggris untuk Tujuan Khusus lebih efektif dibandingkan dengan penggunaan bahan ajar cetak.
\end{abstract}

\begin{abstract}
:
This research is about the development of ICT-based English instructional materials of English for Specific Purpose. The purpose of this study is to determine the type of instructional materials used in English language instruction, develop English for Specific Purpose materials that integrate ICT, and assess the effectiveness of instruction by using ICT-based instructional materials as well as the traditional instruction. The method of research was a research and development. The method of data collection were observation, interviews, study the document, portfolio, and tests. The technique of data analysis in this study used mixed method. The Results showed that ESP materials used in UIN Alauddin looked traditional and they were focused more in using textbook, white board, and face to face interaction. ICT based instruction has been developed systematically and revised based on recommendation, and the use of ICT based instruction is more effective than the one with printed materials.
\end{abstract}

\section{Kata Kunci:}

ESP, Penelitian dan Pengembangan, TIK, Media Pembelajaran

EFEKTIVITAS suatu pembelajaran sangat ditentukan oleh sejauh mana perencanaan yang dilakukan oleh tenaga pengajar. Perencanaan pembelajaran tidak hanya sekadar untuk melengkapi kebutuhan administrasi dan kurikulum, tetapi harus didesain dengan melibatkan komponen-komponen desain instruksional yang meliputi tujuan instruksional yang diawali dengan analisis instruksional, analisis peserta didik dan konteks, merumuskan sasaran kinerja, pengembangan instrumen penilaian, mengem- 
bangkan strategi pembelajaran, mengembangkan dan memilih materi, dan mengembangkan serta melakukan evaluasi formatif dan sumatif. ${ }^{1}$

Namun, pengembangan bahan ajar yang dilakukan selama ini baru dalam batas pengadaan bahan cetak berupa hand out, ringkasan materi, dan materi penyajian dalam bentuk Powerpoint. Bahan cetak lain seperti buku dan modul masih sangat terbatas dihasilkan apalagi kalau bahan ajar berupa audio, visual, dan multi media yang mengintegrasikan Teknologi Informasi dan Komunikasi (TIK). Pengembangan modul hanya sekedar mengumpulkan materi yang langsung diajarkan kepada peserta didik tanpa melakukan analisis kebutuhan dan berbagai proses yang sistemik dan sistematis. Proses penyusunan seperti ini tidak dapat menjangkau kebutuhan peserta didik yang sesungguhnya sehingga materi pembelajaran yang disampaikan cenderung tidak dapat menarik minat peserta didik. Begitu pula, pembelajaran yang hanya mengandalkan handout dan ringkasan materi memang dapat memberikan ringkasan pelajaran yang bisa disampaikan dalam waktu singkat dan dapat dipahami lebih cepat. Tetapi, akibatnya peserta didik hanya dapat memahami secara sederhana aplikasi pembelajaran yang bersifat dangkal. Sedangkan, secara konseptual, teori-teori, postulat, dan rumus-rumus yang membangun pemahaman secara mendalam tidak dapat dijabarkan dengan sistematis dan berkelanjutan.

Bahan ajar yang dikembangkan berdasarkan teori desain instruksional memegang peranan penting dalam menciptakan kondisi belajar yang kondusif. Terdapat tiga alasan mengapa bahan ajar itu memiliki posisi sentral, yakni (1) merupakan representasi sajian tenaga pengajar, (2) sebagai sarana pencapaian tujuan pembelajaran, dan (3) pengoptimalan pelayanan terhadap peserta didik. ${ }^{2}$ Pertama, bahan ajar sebagai representasi dari penjelasan tenaga pengajar di depan kelas. Keterangan-keterangan, uraian-uraian yang harus disampaikan, dan informasi yang disajikan tenaga pengajar dihimpun di dalam bahan ajar. Dengan demikian, tenaga pengajar dapat mengurangi aktivitas untuk menjelaskan sehingga memiliki banyak waktu untuk membimbing pemelajar dalam melakukan aktivitas pembelajaran. Kedua, bahan ajar berkedudukan sebagai alat atau sarana untuk mencapai tujuan. Ketiga, bahan ajar juga merupakan wujud pelayanan satuan pendidikan terhadap peserta didik. Peserta didik berhadapan dengan bahan yang terdokumentasi dan berhubungan dengan informasi yang konsisten sehingga bagi peserta didik yang cepat belajar dapat mengoptimalkan kemampuannya dengan mempelajari bahan ajar tersebut. Sebaliknya, bagi peserta didik yang lamban belajar dapat mempelajari bahan ajar secara berulangulang. Dengan demikian, optimalisasi pelayanan belajar terhadap peserta didik dapat terselenggara dengan baik melalui penggunaan bahan ajar.

Pengembangan adalah salah satu domain teknologi pembelajaran yang berfungsi sebagai proses penerjemahan spesifikasi desain ke dalam bentuk fisik. ${ }^{3}$ Dalam melakukan kegiatan pengembangan, beberapa pertimbangan penting yang perlu dipahami mencakup (1) mengidentifikasi tujuan pembelajaran, (2) melakukan analisis pembelajaran, (3) menganalisis peserta didik dan konteks, (4) menulis tujuan instruksional khusus (kompetensi dasar), (5) mengembangkan instrumen asesmen, (6) meng- 
embangkan strategi pembelajaran, (7) mengembangkan dan menyeleksi materi pembelajaran, (8) mendesain dan melakukan evaluasi formatif, (9) melakukan revisi, dan (10) mendesain dan melakukan evaluasi sumatif.4

Berkaitan dengan pengembangan bahan ajar, perlu memahami teori belajar. Banyak teori belajar yang sudah dikembangkan, tetapi yang paling umum adalah teori belajar behaviorisme, kognitivisme, dan konstruksitivisme. Menurut kaum behaviorisme, belajar adalah perubahan dalam tingkah laku sebagai akibat dari interaksi antara stimulus dan respon. ${ }^{5}$ Belajar menurut kaum behavioris menekankan pada perubahan perilaku yang dapat diamati dari hasil hubungan timbal balik antara guru sebagai pemberi stimulus dan murid sebagai perespon tindakan stimulus yang diberikan. Beberapa teori belajar yang dikembangkan dari teori behavioris adalah teori classical conditioning dari Ivan Pavlov, Connectionism dari Thorndike, dan teori operant conditioning dari Skinner. ${ }^{6}$

Teori connectionism, menekankan pada jaringan asosiasi atau hubungan antara stimulus dan respon yang kemudian disebut $S-R$ bond theory. Dalam hubungan antara stimulus dan respon ini dipengaruhi oleh beberapa faktor, sehingga Thorndike merumuskan tiga hukum belajar, yakni; (1) law of readiness, yaitu bahwa belajar akan terjadi bila ada kesiapan pada diri individu, (2 law of excercise, yaitu bahwa hubungan antara stimulus dan respon dalam proses belajar akan diperkuat atau diperlemah oleh tingkat intensitas dan durasi dari pengulangan hubungan atau latihan yang dilakukan, (3) law of efect, yaitu bahwa hubungan antara stimulus dan respon akan semakin kuat bila suatu respon menghasilkan efek yang menyenangkan. Sebaliknya, apabila respon kurang menyenangkan, maka hubungan antara stimulus dan respon akan melemah.7

Teori operant conditioning, mengatakan bahwa perilaku dalam proses belajar terbentuk oleh sejauh mana konsekuensi yang ditimbulkan. Jika konsekuensinya menyenangkan, maka akan terjadi positive reinforcement berupa reward yang membuat perilaku yang sama terulang lagi, sebaliknya apabila konsekuensinya tidak menyenangkan yaitu negative reinforcement atau punishment akan membuat perilaku dihindari. 8

Teori belajar kognitif justru memberikan tanggapan langsung bahwa belajar bukan hanya dapat diamati melalui perubahan perilaku, melainkan juga perubahan struktur mental internal seseorang yang memberikan kapasitas padanya untuk menunjukkan perubahan perilaku. Struktur mental yang dimaksud mencakup pengetahuan, keyakinan, keterampilan, harapan, dan mekanisme lainnya dalam otak peserta didik. Teori-teori belajar kognitivisme terdiri atas teori cognitive field, teori schema, dan information-processing theory. Pertama, teori belajar cognitive field menjelaskan bahwa yang dimaksud dengan belajar adalah termasuk mental sehingga yang paling berperan adalah motivasi baik berupa ekternal dan motivasi internal.

Kedua, teori schema, beranggapan bahwa schema yang telah menjadi bagian yang sudah terbentuk dalam diri anak akan berguna dalam mengingat pengalaman yang diperoleh melalui beberapa proses seperti menyeleksi, mengambil intisari, dan meng- 
interpretasi yang kemudian dapat dimodifikasi melalui aktivitas yang merujuk pada penambahan, penyesuaian, dan restrukturisasi. Ketiga, information-processing theory menjelaskan bahwa belajar adalah suatu upaya untuk memproses, memperoleh, dan menyimpan informasi melalui short term memory (memori jangka pendek) dan long term memory (memori jangka panjang) ${ }^{9}$

Teori konstruktivis dikembangkan oleh Piaget dengan nama individual cognitive constructivist theory dan Vygotsky dalam teorinya yang disebut social cultural constructivist theory. Piaget telah terkenal dengan teorinya mengenai tahapan dalam perkembangan kognisi. Piaget menemukan bahwa anak-anak berpikir dan beralasan secara berbeda pada periode yang berbeda dalam kehidupan mereka. Pertumbuhan intektual melibatkan tiga proses fundamental; asimilasi, akomodasi, dan aquilibrasi (penyeimbangan). Asimilasi melibatkan penggabungan pengetahuan baru dengan struktur pengetahuan yang sudah ada sebelumnya. Akomodasi berarti perubahan struktur pengetahuan yang sudah ada sebelumnya untuk mengakomodasi hadirnya informasi baru. Penyatuan dua proses asimilasi dan akomodasi inilah yang membuat anak dapat membentuk schema. ${ }^{10}$ Equilibration adalah keseimbangan antara pribadi seseorang dengan lingkungannya atau antara asimilasi dan akomodasi. Bagi Piaget, equilibrasi adalah faktor utama dalam menjelaskan mengapa inteligensi logis seorang anak berkembang lebih cepat dari pada anak yang lainnya.

Vygostsky mengajukan teori yang dikenal dengan istilah Zone of Proximal Development (ZPD) yang merupakan dimensi sosio-kultural yang penting sebagai dimensi psikologis. ${ }^{11}$ ZPD adalah jarak antara tingkat perkembangan actual dengan tingkat perkembangan potensial. Tingkat perkembangan yang dimaksud terdiri atas empat tahap; Pertama, more dependence to others stage, yakni tahapan di mana kinerja anak mendapat banyak bantuan dari pihak lain seperti teman-teman sebayanya, orang tua, guru, masyarakat, ahli, dan lain-lain. Dari sinilah muncul model pembelajaran kooperatif dan kolaboratif dalam mengembangkan kognisi anak secara konstruktif. Kedua, less dependence external assistence stage, di mana kinerja anak tidak lagi terlalu banyak mengharapkan bantuan dari pihak lain, tetapi lebih kepada self assistance, lebih banyak anak membantu dirinya sendiri. Ketiga, Internalization and automatization stage, di mana kinerja anak sudah lebih terinternalisasi secara otomatis. Keempat, Deautomatization stage, di mana kinerjan anak mampu mengeluarkan perasaan dari kalbu, jiwa, dan emosinya yang dilakukan secara berulang-ulang, bolak-balik, recursion. ${ }^{12}$

Selanjutnya, istilah yang banyak digunakan dalam kajian desain dan pengembangan pembelajaran adalah instructional materials (bahan pembelajaran) yang mencakup seluruh bentuk-bentuk pembelajaran seperti petunjuk bagi instruktur, modul peserta didik, Overhead Transparancies (OHP), videotapes, format multimedia berbasis computer, dan web pages untuk pendidikan jarak jauh. ${ }^{13}$ Dalam hubungannya dengan integrasi teknologi ke dalam pembelajaran, bahan ajar juga disebut materials yang biasa dibedakan dengan tools (peralatan), dan devices (perangkat, alat). Peralatan adalah hardware dan software yang digunakan bersama untuk menciptakan video training 
yang disimpan atau diekspor melalui materi. Materi adalah webstrem (digital), video cassette (analog), dan DVD (digital) yang digunakan untuk menyimpan video training yang dinonton melalui perangkat. Sedangkan, perangkat adalah komputer dengan web browser dan quicktime player (digital), VCR (analog), DVD player (digital), dan computer DVD Room (digital) yang digunakan untuk mengakses materi. ${ }^{14}$

Bahan ajar juga disebut learning materials (materi ajar) yang mencakup alat bantu visual seperti handout, slides/overheads, yang terdiri atas teks, diagram, gambar dan foto, plus media lain seperti audio, video, dan animasi. ${ }^{15}$ Selain itu, bahan ajar juga dikenal dengan istilah teaching materials (bahan ajar) yang dipandang sebagai materi yang disediakan untuk kebutuhan pembelajaran yang mencakup buku teks, video dan audio tapes, software computer, dan alat bantu visual.16 Jadi, yang dimaksud dengan bahan ajar di sini adalah seperangkat materi yang disusun secara sistematis untuk kebutuhan pembelajaran baik bersifat bahan cetak (printed material) maupun yang berwujud audio, visual, video, multimedia, dan materi yang berbasis web.

TIK didefinisikan sebagai ilmu yang mempelajari tentang desain, pengembangan, implementasi, manajemen sistem informasi yang berbasiskan komputer, khususnya aplikasi software dan hardware. ${ }^{17}$ Teknologi Informasi menurut definisi ini berhubungan dengan penggunaan komputer secara elektronik dan software komputer untuk mengubah, menyimpan, memproteksi, memproses, mentransmisi, dan memanggil kembali segala informasi secara aman.

Teknologi dipandang sebagai aplikasi sistematis ilmu pengetahuan ilmiah untuk mempraktekan tugas-tugas yang akan dilakukan. Sedangkan belajar atau pembelajaran adalah pengembangan pengetahuan baru, keterampilan, dan sikap serta perilaku seorang individu dalam berinteraksi dengan lingkungan dan informasi. ${ }^{18}$ Dengan demikian, yang dimaksud dengan TIK dalam penelitian ini adalah pemanfaatan manajemen sistem informasi yang merupakan aplikasi software dan hardware dalam menunjang proses belajar mengajar.

Terdapat beberapa jenis teknologi informasi yang biasa digunakan dalam pembelajaran, seperti; Surat Elektronik (E-mail), HP, Kamera digital, MP3 Players, Web Sites, Wikipedia, YouTube.com, Blogging, and Podcasting. ${ }^{19}$ Ketiga teknologi terakhir ini telah banyak memengaruhi pandangan dan persepsi manusia seluruh dunia dengan begitu cepat. YouTube.com adalah website untuk men-sharing video di mana pengguna dapat mengupload melihat, dan membagi video klip (Wikipedia, 2007). YouTube dibuat pada pertengahan bulan Januari 2005 oleh tiga pegawai paypal. Lebih jauh dikatakan bahwa terdapat 100 juta video yang diputar setiap hari, 65,000 video baru yang dimuat, lebih dari 13 juta pengunjung setiap bulan, 58\% of video di Internet dinonton melalui YouTube, Pengguna kebanyakan berumur 18 sampai 35 tahun, dan terjual sebanyak 1,6 juta dolar (US) pada tahun 2006.

Blog atau webblog adalah suatu bentuk website yang menggunakan software tertentu yang latar belakangnya sudah didesain (Hill, 2006). ${ }^{20}$ Blog adalah website yang digunakan untuk menerbitkan hasil karya pribadi. Terdapat 12 juta orang Amerika menulis blogs, 54 juta orang Amerika membaca blogs, membolehkan penulis menulis 
untuk audiens, mudah didapat oleh setiap orang. Dikatakan bahwa pada pertengahan tahun 2005 terdapat 70 juta webblog telah dibuat, 6\% dari penduduk Amerika telah menulis Blog, $16 \%$ dan telah membaca blog-blog yang ada. ${ }^{21}$

Podcasting adalah website yang dapat digunakan untuk menyimpan dan merancang radio sendiri. File audio-nya disimpan berdasarkan sub-skrepsi yang dapat dijadikan sebagai tempat teater penulis dan dapat merekam proses belajar mengajar dalam ruangan kelas. Selain podcasting terdapat juga Google Earth yang merupakan peta browser geografi-suatu alat yang sangat bagus untuk melihat menciptakan, dan men-sharing file-file interaktif yang berisi informasi lokasi khusus secara visual. Semua media dan teknologi tersebut dipandang perlu untuk diintegrasikan ke dalam English for Specific Purpose (ESP).

ESP adalah Bahasa Inggris untuk tujuan khusus. Robinson selanjutnya mengatakan "It (here ESP) is generally used to refer to the teaching and learning of a foreign language for a clearly itilitarian purpose of which there is no doubt."22 Bahasa Inggris untuk Tujuan Khusus (English For Specific Purposes) mempunyai pendekatan dan asumsi yang berbeda dengan General English (GE). Tujuan ESP adalah agar peserta didik mampu menguasai Bahasa Inggris pada bidang yang mereka pelajari. Misalnya mahasiswa kimia, maka mereka harus memahami Bahasa Inggris untuk kimia, atau jika mereka mahasiswa teknik, mereka harus mengetahui Bahasa Inggris untuk teknik, atau jika mereka bekerja di perhotelan, maka mereka harus menguasai Bahasa Inggris perhotelan, jika mereka mahasiswa maritim, maka mereka harus menguasai Bahasa Inggris maritim, dan sebagainya.

Hal senada juga dikatakan oleh Mc Donough tentang definisi dan konsep ESP. Dia berpendapat "ESP courses are those where the syllabus and materials are determined in all essentials by prior analysis of the communication needs of the learners." 23 Pendapat Donough mengindikasikan bahwa materi dan silabus serta tujuan ESP harus dirancang dan dikembangkan berdasarkan kebutuhan mahasiswa dan pengguna lulusan. Jadi pendekatan ESP adalah pendekatan dari bawah ke atas (button up approach).

Berdasarkan uraian di atas, ESP bukan suatu produk baru, tetapi pendekatan khusus dalam pembelajaran Bahasa Inggris yang berbeda dengan Bahasa Inggris umum. ESP merujuk pada pembelajaran Bahasa Inggris yang berorientasi kebutuhan khusus pembelajar sesuai dengan bidang ilmu dan pekerjaan. Materi ESP dikembangkan berdasarkan analisis kebutuhan.

Untuk menunjang proses pembelajaran yang efektif dan efisien baik yang berlangsung secara face to face di dalam ruang kelas maupun untuk kebutuhan pembelajaran mandiri, maka perlu didukung oleh rancangan dan pengembangan bahan ajar yang dapat mengintegrasikan kemampuan kognisi, afeksi, dan psiko-mototik. Oleh karena itu, yang menjadi fokus kajian dalam penelitian ini adalah (1) bahan ajar berbasis media apa saja yang digunakan dalam pembelajaran bahasa Inggris di UIN Alauddin? (2) bagaimana mengembangkan model bahan ajar bahasa Inggris berbasis teknologi informasi dan komunikasi? (3) bagaimana efektivitas model bahan ajar bahasa Inggris yang mengintegrasikan teknologi informasi dan komunikasi? 


\section{METODOLOGI PENELITIAN}

Jenis penelitian yang digunakan adalah penelitian dan pengembangan (research and development) yang dapat didefinisi sebagai "a process used to develop and validate educational products atau suatu proses untuk mengembangkan dan menvalidasi produk pendidikan". ${ }^{4}$ Penelitian ini dikatakan penelitian dan pengembangan (research and development) karena meliputi kegiatan penelitian dan pengembangan model bahan ajar berbasis TIK.

Proses penelitian dan pengembangan meliputi sepuluh langkah, yaitu: (1) mengumpulkan riset dan hasil penelitian, (2) perencanaan, (3) mengembangkan bentuk produk awal, (4) pengujian lapangan pendahuluan, (5) revisi produk utama, (6) uji lapangan utama, (7) revisi produk operasional, (8) uji lapangan operasional, (9) revisi produk akhir, (10) penyebaran dan implementasi. ${ }^{25}$ Namun, mengingat keterbatasan waktu, tenaga, dan dana, kesepuluh langkah tersebut disederhanakan menjadi tiga langkah, yaitu: (1) penelitian pendahuluan, (2) penyusunan model, dan (3) validasi model. ${ }^{26}$

Teknik pengumpulan data yang digunakan dalam penelitian ini adalah: (1) observasi; (2) wawancara; (3) studi dokumen; (4) angket; (5) portofolio. Adapun langkah yang ditempuh dalam mengembangkan validitas (kesahihan) data penelitian adalah: (1) trianggulasi; (2) reviuw informan; (3) Penyusunan data base; dan (3) kehadiran peneliti ke tengah lokasi penelitian.

Analisis data dalam penelitian ini digunakan dua pendekatan, yaitu pendekatan kualitatif dan kuantitatif. Pendekatan kualitatif digunakan karena penelitaian ini berusaha mengembangkan model bahan ajar berbasis TIK, di mana data yang terkumpul dan diolah adalah data kualitatif. Pendekatan kuantitatif digunakan dalam uji efektivitas, yaitu untuk membandingkan tingkat efektivitas antara bahan ajar berbasis TIK dengan bahan ajar konvensional. Dengan demikian dalam pelaksanaan analisis data penelitian ini berusaha memadukan dua pendekatan yang berbeda, sehingga penelitian ini dapat dikatakan menggunakan perpaduan dua metode atau mixed method..27 Subjek penelitian adalah 80 orang peserta didik (mahasiswa) semester VI program studi pendidikan bahasa Inggris fakultas Tarbiyah dan Keguruan UIN Alauddin Makassar tahun akademik 2011/2012.

\section{HASIL PENELITIAN}

\section{Bahan Ajar dalam Pembelajaran English for Specific Purpose}

Untuk mengkaji bahan ajar pembelajaran ESP pada Fakultas Tarbiyah dan Keguruan UIN Alauddin Makassar, dapat dilihat dari tiga perspektif, yakni (1) analisis kondisi bahan ajar, (2) analisis standar kompetensi, kompetensi dasar, dan indikator, dan (3) analisis media pembelajaran yang digunakan. Pertama, ditinjau dari karakteristik ESP sebagai mana dijelaskan oleh Strevens dalam pembahasan sebelumnya, 
yakni (a) ESP dirancang untuk memenuhi kebutuhan pembelajar. (b) substansi dan isi ESP dikaitkan dengan tema dan topik pada bidang ilmu tertentu, jenis pekerjaan atau aktivitas tertentu, (c) berpusat pada bentuk kebahasaan yang sesuai dengan aktivitas dan bidang ilmu atau pekerjaan seperti sintaksis, leksikal, wacana, semantik, dan sebagainya, dan d) ESP berbeda dengan General English, maka dapat dikatakan bahwa bahan ajar yang tersedia sebagai mana ditunjukkan dalam silabus mata kuliah ESP baru memenuhi sebagian dari seluruh karakteritik yang ada. Berdasarkan analisis tentang kebutuhan mahasiswa jurusan Pendidikan Bahasa Inggris Fakultas Tarbiyah Semester VI, ESP belum diarahkan pada bidang keilmuan ketarbiayaan dan Keguruan yang dipayungi oleh konteks ke-UIN-an. Dengan kata lain, ESP yang dikembangkan pada jurusan Pendidikan bahasa Inggris belum diarahkan pada bidang keilmuan Pendidikan dan keguruan yang dilingkupi bidang kajian keislaman.

ESP juga belum berpusat pada bentuk kebahasaan yang sesuai dengan aktivitas dan bidang keilmuan atau pekerjaan. Secara linguistik, bentuk bahasa yang paling terkecil dapat dianalisis secara komprehensif melalui fonetik dan fonologi yang bidang kajiannya menggarap hal-hal yang berhubungan dengan bunyi dan fonem. Pada level kosa kata dengan segala kategori dan struktur pembentukannya dianalisis dalam bidang kajian morphology, kemudian pada level kalimat yang mencakup frasa dan klausa dikaji secara mendalam melalui bidang keilmuan sintaksis. Di samping itu, receptive skills seperti listening dan reading serta productive skills seperti speaking dan writing merupakan bagian yang terpisahkan dengan ESP.

Materi pembelajaran sebagaimana dijelaskan dalam silabus ESP yang telah disajikan sebelumnya lebih berorientasi pada bahasa Inggris umum dari pada masuk dalam kategori ESP. Artinya materi bahasa ESP saat ini belum sesuai dengan kebutuhan mahasiswa Pendidikan Bahasa Inggris Semster VI.

Berdasarkan deskripsi Bahan Ajar yang digunakan dalam Pembelajaran di UIN Alauddin Makassar, maka dapat dikatakan bahwa bahan ajar tersebut memiliki kelemahan sebagai berikut:

1. Belum menggambarkan substansi dan isi ESP dikaitkan dengan tema dan topik pada bidang ilmu tertentu, jenis pekerjaan atau aktivitas tertentu,

2. Belum berpusat pada bentuk kebahasaan yang sesuai dengan aktivitas dan bidang ilmu atau pekerjaan seperti sintaksis, leksikal, wacana, dan semantik.

3. Pembelajaran ESP masih bersifat tradisional yang hanya mengandalkan buku teks, papan tulis, dan kehadiran langsung dosen dalam ruang kelas. Padahal berbagai fasilitas seperti ketersediaan Internet dan fasilitas penunjang telah tersedia.

Kedua, berdasarkan hasil analisis terhadap Standar Kompetensi (SK), Kompetensi Dasar (KD), dan indikator yang dirujuk dari keterampilan tingkat tinggi dan keterampilan berpikir tingkat rendah Benyamin S Bloom atau dikenal dengan istilah Taksonomi Bloom, yaitu: 


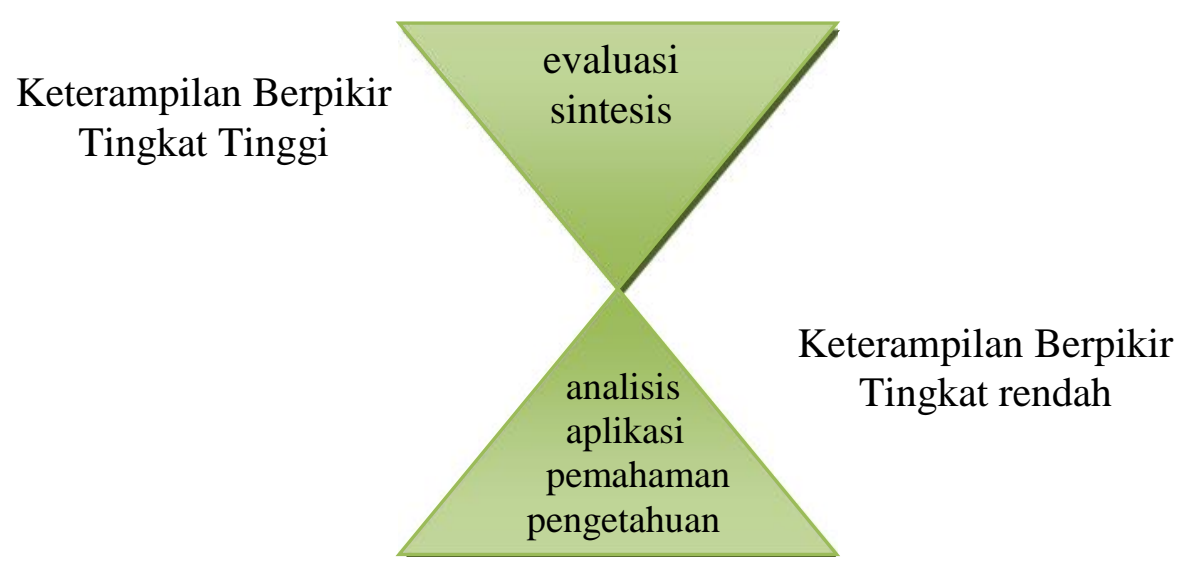

Gambar 1. Domain Kognisi

Maka standar kompetensi dan kompetensi dasar yang didesain dalam silabus untuk mata kuliah English for Specific Purpose masih berada pada tingkat perpikir rendah atau berada pada tingkat kedua dalam desain Anderson. Hal ini penting untuk dipahami karena pembelajaran bahasa Inggris dilakukan pada tingkat pendidikan tinggi dan perlu diarahkan pada kompetensi yang lebih tinggi seperti pada tingkat menerapkan, menganalisis, mengevaluasi, dan menciptakan atau pada level penerapan, analisis, sintesis, dan evaluasi menurut taksonomi Bloom.

Ketiga, analisis media pembelajaran. Di sini peneliti merujuk pada pandangan Bretz $^{28}$ dalam mengidentifikasi karakteristik media yang terdiri atas tiga unsur pokok; audio, visual, dan gambar bergerak.

Berdasarkan analisis tentang karakteristik media, maka media pembelajaran yang digunakan dalam menyajikan materi pembelajaran pada mata kuliah ESP adalah media visual lebih khusus pada media cetak karena hanya mengandalkan buku paket dan pembelajaran face to face yang hanya berlangsung dengan setting ruang kelas secara tradisional.

\section{Bahan Ajar Bahasa Inggris Berbasis TIK}

Hasil analisis kebutuhan menunjukkan bahwa bahan ajar bahasa Inggris dalam mata kuliah English for Specific Purpose (ESP) pada Jurusan Pendidikan Bahasa Inggris, Fakultas Tarbiyah dan Keguruan UIN Alauddin Makassar Semester VI masih mengandalkan buku teks dan cenderung cocok dengan level pendidikan menengah sehingga berfungsi sekadar menyampaikan materi pembelajaran kepada mahasiswa sehingga tujuan pembelajaran tidak tercapai dan bahkan menjadikan ESP sebagai mata kuliah yang diremehkan dan tidak memberikan kontribusi signifikan. Sehubungan dengan hal tersebut maka perlu diupayakan pembenahan dengan mengembangkan bahan ajar berbasis ICT khususnya pemanfaatan media Web Blog sebagai media interaksi di samping pertemuan face to face.

Mengingat kelemahan bahan ajar yang meliputi seluruh komponen ditinjau dari karakteristik ESP sebagaimana dijelaskan sebelumnya, maka dalam pengembangan 
bahan ajar dengan mengintegrasikan Web Blog dalam pembelajaran dilakukan secara sistemik, yaitu meliputi seluruh komponen yang terkait dengan proses pengembangan bahan ajar, yaitu aspek analysis, tujuan, dan evaluasi. Hal ini sesuai dengan model desain yang dikembangkan oleh Dick \& Carey yang menjadi rujukan dalam mengembangkan bahan ajar ESP berbasis Web Blog.

Pengembangan tersebut mencakup beberapa tahap; (1) merancang tujuan Instruksional, (2) analisis instruksional (3) analisis pengetahuan prasyarat dan karakteristik peserta didik (4) menyusun kompetensi atau kinerja yang diinginkan, (5) mengembangkan instrumen (6) menyusun strategi instruksional, (7) menyusun bahan ajar yang sesuai (8) melakukan evaluasi formatif, dan (9) melakukan evaluasi sumatif. Hasil akhir yang diharapkan dalam mendesain pembelajaran ESP berbasis TIK, dapat dinyatakan dalam Tujuan Akhir English for Specific Purpose Mahasiswa Jurusan Pendidikan Bahasa Inggris Fakultas Tarbiyah UIN Alauddin Makassar Semester VI mampu memahami konsep pendidikan Islam, konsep ilmu pengetahuan, pandangan berbagai ilmuan islam tentang tujuan pendidikan Islam, sistem pendidikan, aspekaspek pedagogik, etika dalam ilmu pengetahuan, metode, hasil kreativitas, institusi, dan organisasi dalam Islam. Mahasiswa juga mampu menjelaskan disertai contoh, mengonstruksi ide-ide kritis dalam menyajikan pandangan baik secara lisan tertuis, menghubungkan pandangan-pandangan ilmuan islam dengan pandangan ilmuan Barat tentang pendidikan, mendiskusikan, membandingkan konsep pendidikan Islam dan barat, mengkaji isi bacaan dan mengeritisi dalam bentuk tertulis, membuat rangkuman tertulis, mengembangkan ide-ide mereka untuk menyelesaikan solusi terhadap permasalahan pendidikan Islam seperti yang tertera dalam isi bacaan dengan memanfaatkan media web blog sebagai media dalam pembelajaran. Adapun tujuan tersebut kemudian dikembangkan melalui analisis instruksional dengan memadukan antara SK dan KD dengan domain pengetahuan.

Setelah menganalisis pembelajaran, pengetahuan prasyarat, kompetensi dan kinerja, instrumen, strategi, materi, dan evaluasi kemudian dimuat materinya dibuat dalam WEB-Blog.

Dalam upaya menyempurnakan hasil pengembangan bahan ajar English for Specific Purpose, dilakukan validasi dalam bentuk: (a) diskusi/seminar dengan praktisi dan (b) validasi pakar (expert judgement). Kegiatan diskusi dengan para praktisi dimaksudkan untuk mendapat masukan terhadap bahan ajar yang dikembangkan. Diskusi ini dilaksanakan dengan dosen pendidikan Bahasa Inggris baik yang berada di Makassar maupun yang sedang melanjutkan S3 pada Universitas Negeri Jakarta. Masukan yang didapat dari kegiatan diskusi dengan para dosen dapat dirangkumkan sebagai berikut:

1. Para dosen merasa senang dengan adanya pengembangkan bahan ajar berbasis ICT khususnya melalui Web-blog sehingga mereka dapat menyimpan materi pembelajaran yang akan diberikan kepada mahasiswa. namun Web blog-nya tidak perlu terlalu ramai dengan warna-warni. 
2. Para dosen kurang sepaham dengan upaya hanya pembelajaran online dan tidak perlu adanya pertemuan face to face mengingat kemampuan keuangan mahasiswa belum memungkinkan untuk selalu pergi ke Warnet.

3. Tujuan pembelajaran yang telah dikembangkan tidak perlu mencakup seluruh aspek dalam tingkatan berpikir yang penting dapat mengembangkan setahap demi setahap.

4. Perlu adanya petunjuk teknik tentang cara memposting, memberikan komentar agar mahasiswa mudah melakukannya.

5. Dalam pelaksanaan penilaian harus dapat mengukur keempat keterampilan bahasa dan bukan hanya reading dan writing saja.

Evaluasi pakar dilaksanakan dengan dua pakar, Kedua pakar tersebut adalah Dr. Hadi Sutopo, M. Sc. Seorang Pakar Information Teknologi (IT) sekaligus sebagai pakar dalam teknologi pembelajaran. Selain itu, Dr. Alek Abdullah sebagai pakar dalam bidang English for Spesific Purpose. Masukan dan penilaian dari kedua pakar dapat dirangkum dalam uraian berikut.

1. Secara umum, bahan ajar ini dinilai baik dan merupakan terobosan baru dalam upaya meningkatkan mutu pembelajaran bahasa Inggris di Perguruan tinggi Islam. Oleh karena itu disarankan agar pengembangan bahan ajar ini tidak hanya dilakukan pada mata kuliah ESP melainkan untuk mata kuliah-mata kuliah lainnya.

2. Upaya mengintegrasikan ICT ke dalam pembelajaran bahasa Inggris khususnya dan pembelajaran lain umumnya harus dikembangkan dan perlu memberikan pelatihan kepada dosen-dosen sehingga mereka melakukan hal yang sama dalam mata kuliah yang mereka ampuh.

3. Pemanfaatan sumber dan bahan pembelajaran hendaknya disesuaikan dengan kondisi dan kemampuan perguruan tinggi. Secara konseptual, perguruan tinggi Islam seharusnya sudah melakukan integrasi teknologi ke dalam pembelajaran, tapi kenyataannya kemampuan dosen dan sarana Internet di lingkungan kampus masih sangat terbatas sehingga mengalami kesulitan untuk diterapkan seara serentak.

4. Penilaian yang dikembangkan hendaknya bukan diarahkan pada penguasaai materi yang disampaikan melainkan menilai pencapaian tujuan pembelajaran, yaitu standar kompetensi yang ada.

5. Peneliti harus lebih berani dalam melakukan kritik terhadap kurikulum bahasa Inggris yang ada di lingkungan UIN Alauddin Makassar saat ini.

Masukan dari pakar tersebut cukup baik dan sangat bermanfaat untuk memperbaiki dan menyempurnakan bahan ajar English for Specific Purpose. Masukan lain, berupa koreksi yang bersifat redaksional, sehingga tidak begitu mengubah substansi bahan ajar yang dikembangkan.

\section{Uji Efektivitas}

Dalam pengembangan bahan ajar ESP ini dilakukan Uji coba pada kelompok 3 dan 4 sebagai kelompok perlakuan yang menggunakan TIK dan kelompok 5 dan 6 
sebagai kelompok pembanding yang menggunakan bahan dan media konsensional atau tradisional. Artinya, kelompok 3 dan 4 diberi materi dengan menggunakan bahan ajar berbasis ICT sedangkan pada kelompok 5 dan 6 diberi materi yang sama tapi tidak memakai ICT.

Dalam uji efektivitas, peneliti mengguakan pendekatan kualitatif dan kuantitatif atau yang biasa disebut dengan mixed method. Namun, unsur kualitatifnya lebih banyak dibandingkan dengan kuantitatif. Dalam hubungannya dengan uji efektifitas, skor yang diperoleh kelompok TIK dan kelompok tradisional (tidak menggunakan TIK) dalam pre-test dan post-test dihitung berdasarkan analisis kuantitatif. Sedangkan, reaksi masing-masing kelompok terhadap pembelajaran dikumpulkan melalui observasi dan wawancara dan dianalisis secara kualitatif. Adapun perbandingan antara kelompok TIK dan Tradisional dapat dilihat dalam histogram di bawah ini.

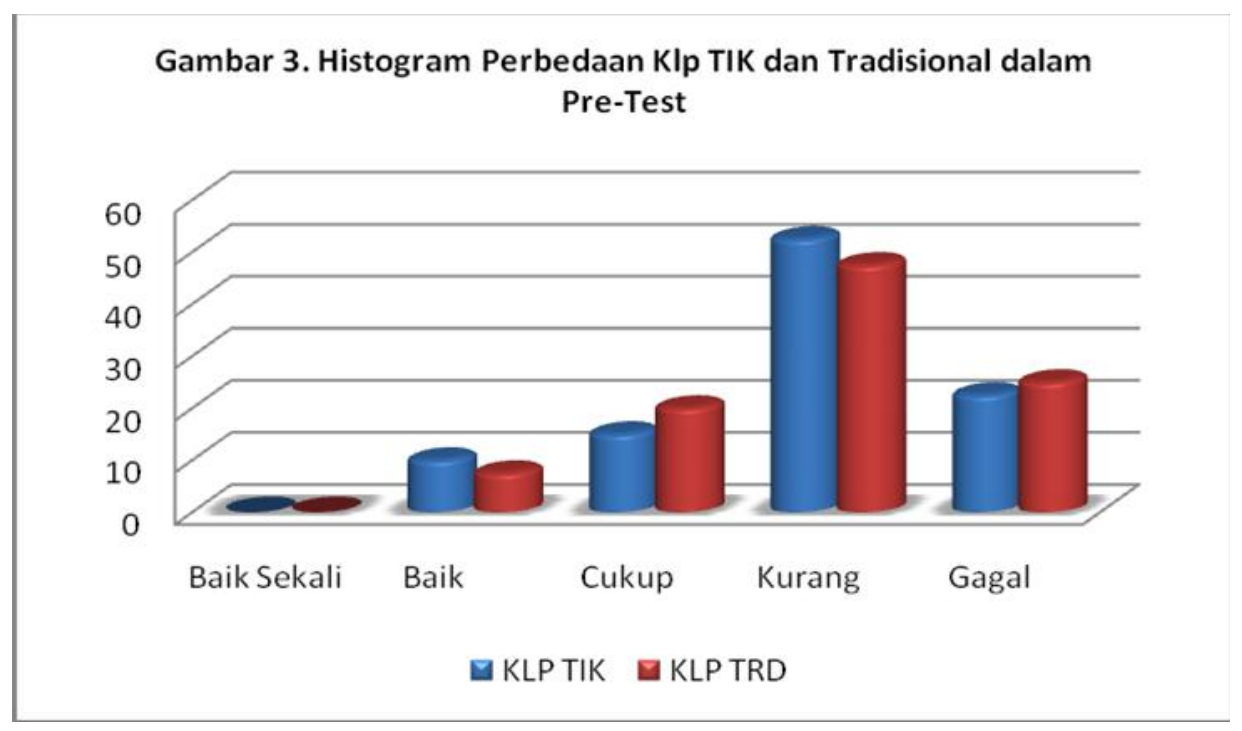

Gambar 3. Histogram Perbedaan Kelompok TIK dan Tradisional dalam Pre-test

Berdasarkan histogram pada gambar 3 di atas menunjukkan bahwa perbedaan skor dalam pre-test antara kelompok TIK dan tradisional tidak menunjukkan perbedaan yang terlalu jauh, di mana kedua kelompok sama-sama tidak memeroleh skor baik sekali. Pada tingkat baik antara rentang skor 66-79, terdapat 4 (10\%) responden pada kelompok TIK dan $3(7,5 \%)$ responden dari kelompok tradisional. Pada rentang nilai 56-65 (cukup), terdapat 21 (52,5\%) responden dari kelompok TIK dan terdapat 19 $(47,5 \%)$ dari kelompok tradisional. Sedangkan, pada rentang skor 30-39 (gagal), terdapat 9 (22,5\%) dari kelompok TIK dan 10 (25\%) dari kelompok tradisional. Setelah menggunakan pembelajaran berbasis TIK dan berbasis media cetak, kedua kelompok tersebut menunjukkan hasil yang berbeda, sebagaimana tergambar dalam histogram sebagai berikut: 


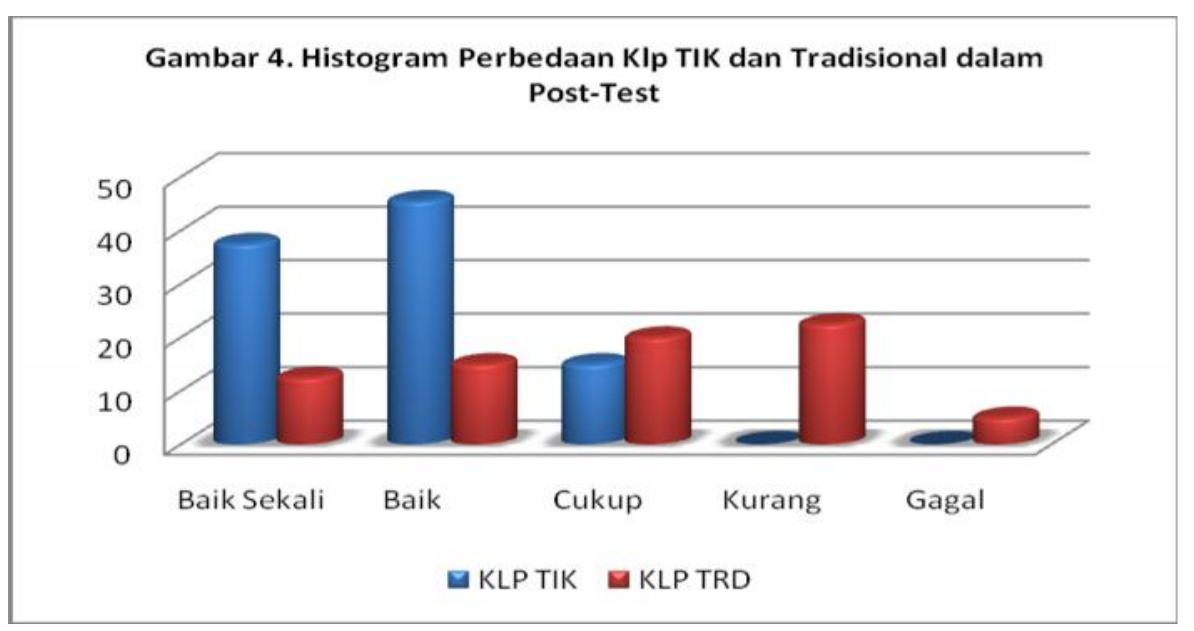

Gambar 4. Histogram Perbedaan Kelompok TIK dan Tradisional dalam Post-test

Hasil post-test sebagaimana ditunjukkan dalam histogram di atas menunjukkan bahwa skor yang diperoleh kelompok TIK jauh lebih tinggi dari skor yang diperoleh kelompok tradisional. Terdapat $15(37,5 \%)$ responden dari kelompok TIK, tetapi hanya $5(12,5 \%)$ responden dari kelompok tradisional yang mencapai skor baik sekali (80-100). Terdapat $19(47,5 \%)$ responden dari kelompok TIK, hanya $6(15 \%)$ responden dari kelompok tradisional mencapai skor baik (60-79). Terdapat $6(15 \%)$ responden dari kelompok TIK, 8 (20\%) responden dari kelompok tradisional mendapat skor cukup (56-65). Sementara itu, tidak terdapat $0(0 \%)$ responden dari kelompok TIK dan sebanyak $9(22,5 \%)$ responden dari kelompok tradisional memperoleh skor kurang (40-55). Terakhir, tidak terdapat 0 (0\%) dari kelompok TIK dan sebanyak 2 (5\%) responden dari kelompok tradisional memperoleh skor gagal (30-39).

Di sisi lain, hasil pengamatan, portofolio, dan wawancara tentang efektivitas bahan ajar ESP berbasis ICT pada Jurusan Pendidikan Bahasa Inggris Fakultas Tarbiyah dan Keguruan UIN Alauddin Makassar menunjukkan bahwa pada kelompok yang menggunakan bahan ajar berbasis ICT tampak lebih aktif dan antusias dalam proses pembelajaran. Mahasiswa merasa tertarik dan tertantang untuk selalu mencoba dan mengulang posting sehingga dapat mengakses pembelajaran melalui HP walaupun mereka berada di mana saja. Keaktifan mahasiswa lebih tampak dalam diskusi, baik diskusi kelompok maupun diskusi kelas, yaitu berusaha mempertahankan pendapat sesuai dengan persepsi masing-masing. Keaktifan mahasiswa dalam berdebat ini menunjukkan suatu wujud penghayatan responden terhadap permasalahan yang dikaji. Adapun kondisi pembelajaran pada kelas tradisional tampak pasif dan tidak bersemangat dalam menerima pelajaran.

Selain dari segi aktivitas yang menunjukkan perbedaan yang mencolok juga tampak pada hasil atau dampak dari proses pembelajaran tersebut. Responden pada kelas yang menerapkan pembelajaran berbasis ICT yang terdorong semangatnya untuk belajar, lebih berminat pada mata kuliah ESP dan timbul rasa ingin tahu untuk mempelajari atau mengakaji berbagai peristiwa secara online. 
Perbedaan efektivitas pembelajaran ini lebih tampak dalam portofolio yang dibuat responden. Portofolio dari kedua kelas tersebut dinilai dengan menggunakan penilaian rubrik, yaitu penilaian ditinjau dari kemampuan writing dan hasil pengumpulan sumber materi yang berasal dari berbagai sumber. Jumlah referensi yang diperoleh kelompok TIK dua-empat kali lipat lebih banyak dibandingkan dengan jumlah referensi yang diperoleh oleh kelompok tradisional. Dengan demikian, pembelajaran yang menggunakan TIK jauh lebih efektif dari pembelajaran yang menggunakan media tradisional seperti bahan cetak.

\section{SIMPULAN DAN IMPLIKASI PENELITIAN}

\section{Simpulan}

Berdasarkan hasil temuan dalam penelitian, beberapa kesimpulan dapat diuraikan seperti di bawah ini:

1. Bahan Ajar dalam Pembelajaran English for Specific Purpose pada Jurusan pendidikan bahasa Inggris semester VI belum menggambarkan substansi dan isi ESP dikaitkan dengan tema dan topik pada bidang ilmu tertentu, jenis pekerjaan atau aktivitas tertentu, belum berpusat pada bentuk kebahasaan yang sesuai dengan aktivitas dan bidang ilmu atau pekerjaan seperti sintaksis, leksikal, wacana, dan semantik. Pembelajaran ESP masih bersifat tradisional yang hanya mengandalkan buku teks, papan tulis, dan kehadiran langsung dosen dalam ruang kelas. Padahal berbagai fasilitas seperti ketersediaan Internet dan fasilitas penunjang telah tersedia.

2. Pengambangan bahan ajar bahasa Inggris berbasis teknologi informasi dan komunikasi mencakup beberapa tahap, yakni tahap (1) merancang tujuan Instruksional, (2) analisis instruksional (3) analisis pengetahuan prasyarat dan karakteristik peserta didik (4) menyusun kompetensi atau kinerja yang diinginkan, (5) mengembangkan instrumen (6) menyusun strategi instruksional, (7) menyusun bahan ajar yang sesuai (8) melakukan evaluasi formatif, dan (9) melakukan evaluasi sumatif. Web-blog tidak perlu terlalu ramai dengan warna-warni, pemanfaatan web-blog tidak meninggalkan pertemuan face to face, tujuan pembelajaran harus disesuaikan dengan tingkat berpikir, dan pelaksanaan penilaian harus dapat mengukur keempat keterampilan bahasa dan bukan hanya reading dan writing saja.

3. Model bahan ajar bahasa Inggris yang mengintegrasikan TIK lebih efektif dibandingkan dengan bahan ajar yang tidak mengintegrasikan TIK atau pembelajaran tradisional. Hal ini menunjukkan bahwa hasil post-test memperlihatkan terdapat 34 (85\%) responden dari kelompok TIK dan hanya 11 (27,5\%) responden dari kelompok tradisional mendapat skor baik dan baik sekali. Padahal hasil pre-test menunjukkan tingkat yang hampir sama, yaitu 4 (10\%) responden dari kelompok TIK dan 3 (7,5\%) responden dari kelompok tradisional berada pada skor baik dan amat baik. 


\section{Implikasi Penelitian}

Penelitian ini tidak mengkaji seluruh komponen teknologi informasi dan komunikasi seperti podcasting, you tube, web two, scribd, 4 shared, interactive software, dan berbagai komponen lainnya. Diharapkan komponen-komponen tersebut dijadikan fokus kajian oleh para peneliti-peneliti lain yang akan datang. Perguruan tinggi Islam di Indonesia seharusnya mengintegrasikan TIK dalam pembelajaran dan memikirkan berbagai fasilitas penunjang, utamanya konektifitas Internet yang memadai.

\section{CATATAN AKHIR:}

1. Dick and carey, The Systemstic Design of Instruction, Sixth Edition (New York:Pearson, 2005) hal. $1-361$.

2. Zulkarnaini, Pembelajaran dengan Bahan Ajar Buatan Guru, hal. 5, 2009 (http://zulkarnainidiran.wordpress.com/2009/06/28/pembelajaran-dengan-bahan-ajar-buatan-guru/).

3. Barbara Seels, dan Rita Richey, The Defination And Domain Of The Field. (Association For Educational Communication And Technonology. Washington DC, 1994), hal. 35.

4. Walter Dick, Lou Carey, and James O. Carey, op.cit., p. 6-8.

5. Margaret Bell Gredler, Learning and Instruction Theory Into Practice., (New York: McMillan Publishing Company: 1986), p. 42.

6. Anita Woolfolk, Educational Psychology. (Boston: Pearson Education Inc, 2004), pp. 20-203

7. Paul Eggen dan D. Kauchak, Educational Psychology Windows on Classrooms (USA: Prentice Hall Inc, 1997), pp. 198-199.

8. Ibid, pp. 204-205

9. James P. Byrnes, Cognitive Development and Learning in Instructional Contexts (Boston: Allyn and Bacon, 1996), pp. 24-25

10. Jean Piaget. Approach to Learning and the Development of the Intelect dalam Robert M.W. Travers, Essentials of Learning. Fourth Edition (New York : Macmillan Publishing Co., Inc. 1977), p 147-154.

11. Vigotsky. Thought and Language. Combridge. (The Mitt Press. London, 1977) p 23

12. Conny Semiawan, "Perkembangan Anak Usia Dini", Makalah dalam Seminar Pendidikan Nasional Anak Usia Dini (Jakarta: Ditjen PLS dan Pemuda Depdiknas dengan UNJ, 9 - 11 Oktober. 2004), p. 8

13. Walter Dick, Lou Carey, and James O. Carey, Opcit. Hal. 7.

14. Antony Karl Betrus dalam Alan Januszewski dan Michael Molenda, Educational technology: A Definition with Commentary (New York: Lawrence Erlbaum Associates, 2008), p. 225 .

15. Christopher Butcher, Clara Davies, dan Melissa Highton, From Module Outline to Effective Teaching (New York: Routledge, 2006) p.130.

16. Doshisha Kenji Kitao and Doshisha S. Kathleen Kitao, Selecting and Developing Teaching/ Learning Materials, 2009, p. 4, (http://iteslj.org/Articles/Kitao-Materials.html).

17. Wikipedia, Information Technology, 2009, p. 1 (http://en.wikipedia.org/wiki/Information_technology).

18. Heinich, R., Molenda, M., Russell, J. D., \& Smaldino, S. E. (Instructional media and technologies for learning. Seventh edition. Upper Saddle River, New Jersey: Pearson Education), 2002. Hal. 5.

19. Leigh Zeitz, Technology Integration Plan, unpublished paper UIN: USA, 2005. Hal. 16.

20. Wikipedia (http://en.wikipedia.org/wiki/Blog) 2007, hal 1. 
21. Opcit. 32

22. Paulina Robinson, English For Specific Purposes (Oxford: Pergamon Press, Ltd, 1990), p.5.

23. Jo.Mc. Donough. ESP in Perspective A Practical Guide. (London: Collin ELT, 1984), p.3.

24. W.R. Borg . \& Gall, M.D.. Educationnal Research. (London: Longman, 1983), hal. 772

25. W.R. Borg . \& Gall, M.D, op.cit.hal. 784-785

26. Sukmadinata, N.A., Pengembangan Kurikulum Teori dan Praktek (Bandung: PT Remaja Rosdakarya, 2001), hal. 14.

27. Julia Branner, Mixing Methods: Qualitative and Quantitative Research (New York: Ashgate Publishing Company, 1995), p.11

28. Michael Rudy Bretz, Media for interactive communication (London: Sage Publications, 1983), h. 201.

29. R. Gagne dalam Binus, Conditions of Learning, Online; http://lrc.binus.ac.id/downloads/TE/Gagne.pdf. (Diakses Pada 20 Maret 2012).

30. Sharon E. Smaldino, Deborah L. Lowther, dan James, D. Russell, Instructional Technology and Media for Learning (Columbus: Pearson, 2008), h.7.

\section{DAFTAR PUSTAKA:}

Alan, Januszewski \& Molenda, Michael. 2008. Educational Technology: A Definition with Commentary . Taylor \& Prancis Group. New York.

Binus. Conditions of Learning, Online; http://lrc.binus.ac.id/downloads/TE/Gagne.pdf (Diakses Pada 20 Maret 2012).

Borg, W.R. dan Gall, M.D. Educationnal Research. London: Longman, 1983.

Branner, Julia. 1995. Mixing Methods: Qualitative and Quantitative Research. Ashgate Publishing Company. New York.

Bretz, Michael Rudy. Media for interactive communication. London: Sage Publications, 1983.

Byrnes, James P. 1996. Cognitive Development and Learning in Instructional Contexts, Allyn and Bacon. Boston.

Butcher, Christopher, Davies, Clara, dan Highton, Melissa. Module Outline to Effective Teaching. New York: Routledge, 2006.

Davies, Christopher Butcher Clara, dan Melissa Highton. 2006. From Module Outline to Effective Teaching . Routledge. New York.

Dick, W And Carey, L.2005. The Sistematic Desain Of Instruktional. Allyn And Bacon, Boston.

Donough, Jo.Mc. ESP in Perspective A Practical Guide. London: Collin ELT, 1984.

Eggen, Paul dan D. Kauchak. 1977. Educational Psychology Windows on Classrooms Prentice Hall Inc. USA.

Gredler, Margaret Bell. 1986. Learning and Instruction Theory Into Practice., McMillan Publishing Company. New York.

Heinich, R., Molenda, M., Russell, J. D., \& Smaldino, S. E. 2002. Instructional media and technologies for learning. Seventh edition. Pearson Education.Upper Saddle River, New Jersey.

Kitao, Doshisha Kenji and Doshisha S. Kathleen Kitao. 2009. Selecting and Developing Teaching/Learning Materials. (http://iteslj.org/Articles/Kitao-Materials.html).

Miles dan A.M. Huberman, M.B. Qualitative Data Analysis : A Sourcebook of New Methods London New Delhi : Sage Publications, 1984.

Patton, M.Q. Qualitative Evaluation Methods, London : Sage Publications, 1983.

Piaget, Jean. 1977. Approach to Learning and the Development of the Intelect, dalam Robert M.W. Travers, Essentials of Learning. Fourth Edition . Macmillan Publishing Co., Inc.New York. 
Robert K. Yin, Case Study Research : Design and Methods, Baverly Hills, London New Delhi: Sage Publications, 1987.

Robinson, Paulina. English For Specific Purposes. Oxford: Pergamon Press, Ltd, 1990.

Sells,B.B. dan Richey,R.C. 1994. The Defination And Domain Of The Field. Association For Educational Communication And Technonology. Washington DC.

Semiawan, Conny Semiawan. 2004. "Perkembangan Anak Usia Dini", Makalah dalam Seminar Pendidikan Nasional Anak Usia Dini (Jakarta: Ditjen PLS dan Pemuda Depdiknas dengan UNJ, 9 - 11 Oktober. 2004), p. 8

Smaldino, Sharon E., Lowther, Deborah L, dan Russell, James, D. Instructional Technology and Media for Learning. (Columbus: Pearson, 2008.

Spradley, J.P. Partisipan Observation, New York : Holt, Rinehart, and Winston,1980.

Sukmadinata, N.A. 2001. Pengembangan Kurikulum Teori dan Praktek PT Remaja Rosdakarya. Bandung.

Sutopo, H.B. Metode Penelitian Kualitatif: Metodologi Penelitian untuk Ilmu-ilmu Sosial dan Budaya Surakarta : Pusat Penelitian UNS, 1988.

Vigotsky,L. 1987. Thought and Language. Combridge. The Mitt Press. London.

Woolfolk, Anita. Educational Psychology. Boston: Pearson Education Inc, 2004.

W.R. Borg . \& Gall, M.D.1983. Educationnal Research. (London: Longman.

Wikipedia, Information Technology, 2009, p. 1 (http://en.wikipedia.org/wiki/Informationtechnology).

Zeitz, Leigh. 2005. Technology Integration Plan, unpublished paper UIN. USA.

Zulkarnaini. 2009. Pembelajaran dengan Bahan Ajar Buatan Guru. (http://zulkarnainidiranwordpress.com/2009/06/28/pembelajaran-dengan-bahan-ajar-buat-an-guru/). 